Once you have Acrobat Reader open on your computer, click on the Comment tab at the right of the toolbar:

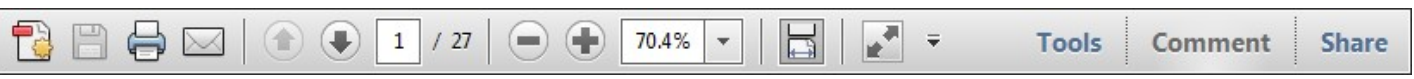

This will open up a panel down the right side of the document. The majority of tools you will use for annotating your proof will be in the Annotations section, pictured opposite. We've picked out some of these tools below:

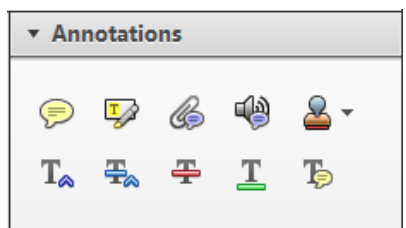

1. Replace (Ins) Tool - for replacing text.

莒合 Strikes a line through text and opens up a text box where replacement text can be entered.

\section{How to use it}

- Highlight a word or sentence.

- Click on the Replace (Ins) icon in the Annotations section.

- Type the replacement text into the blue box that appears.

ıdard tramework for the analysis of $\mathrm{m}$ icy-Nevertheless, it alsoled to exog،

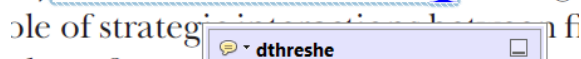
aber of comp 08/06/2011 15:58:17

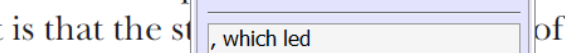
nain compo: be level, are exc nc

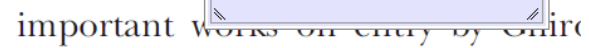
M haneofarth) ${ }^{1}$ we snon the 'hlarl t

3. Add note to text Tool - for highlighting a section to be changed to bold or italic.

T) Highlights text in yellow and opens up a text box where comments can be entered.

\section{How to use it}

- Highlight the relevant section of text.

- Click on the Add note to text icon in the Annotations section.

- Type instruction on what should be changed regarding the text into the yellow box that appears.

namic responses of mark ups ent with the VAR evidence

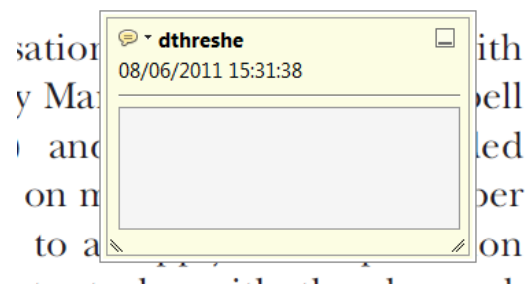

\section{Strikethrough (Del) Tool - for deleting text.}

Strikes a red line through text that is to be deleted.

\section{How to use it}

- Highlight a word or sentence.

- Click on the Strikethrough (Del) icon in the Annotations section.

there is no room for extra profits al c ups are zero and the number of ret) values are not determined by Blanchard and Kiyetaki (1987), rfect competition in general equilil ts of aggregate demand and supply lassical framework assuming monol sen an evorenous number of firme

4. Add sticky note Tool - for making notes at specific points in the text.

Marks a point in the proof where a comment needs to be highlighted.

How to use it

- Click on the Add sticky note icon in the Annotations section.

- Click at the point in the proof where the comment should be inserted.

- Type the comment into the yellow box that appears.

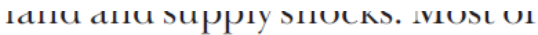

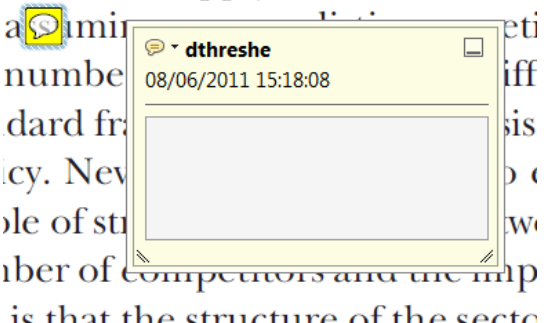


5. Attach File Tool - for inserting large amounts of text or replacement figures.

Inserts an icon linking to the attached file in the appropriate place in the text.

\section{How to use it}

- Click on the Attach File icon in the Annotations section.

- Click on the proof to where you'd like the attached file to be linked.

- Select the file to be attached from your computer or network.

- Select the colour and type of icon that will appear in the proof. Click OK.

END

8

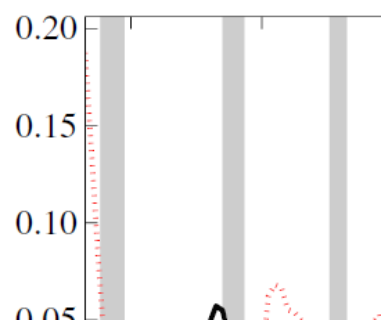

6. Drawing Markups Tools - for drawing shapes, lines and freeform annotations on proofs and commenting on these marks.

Allows shapes, lines and freeform annotations to be drawn on proofs and for comment to be made on

these marks.

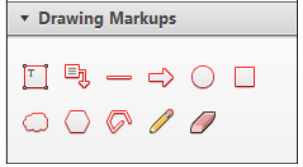

How to use it

- Click on one of the shapes in the Drawing Markups section.

- Click on the proof at the relevant point and draw the selected shape with the cursor.

- To add a comment to the drawn shape, move the cursor over the shape until an arrowhead appears.

- Double click on the shape and type any text in the red box that appears.

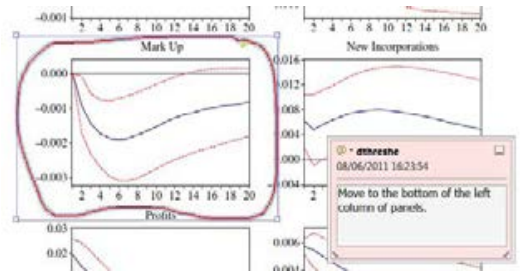




\title{
Analyzing and Interpreting Lime Burials from the Spanish Civil War (1936-1939): A Case Study from La Carcavilla Cemetery*
}

\begin{abstract}
Over 500 victims of the Spanish Civil War (1936-1939) were buried in the cemetery of La Carcavilla (Palencia, Spain). White material, observed in several burials, was analyzed with Raman spectroscopy and powder XRD, and confirmed to be lime. Archaeological findings at La Carcavilla's cemetery show that the application of lime was used in an organized way, mostly associated with coffinless interments of victims of Francoist repression. In burials with a lime cast, observations made it possible to draw conclusions regarding the presence of soft tissue at the moment of deposition, the sequence of events, and the presence of clothing and other evidence. This study illustrates the importance of analyzing a burial within the depositional environment and taphonomic context.
\end{abstract}

KEYWORDS: forensic science, forensic archaeology, Spanish Civil War, mass grave, lime, Raman spectroscopy, identification

The inclusion of lime in burials is observed in historical and archaeological records, in contemporary mass graves, and in forensic cases. However, the lime in those burials is not always examined and often only mentioned. Forensic scientists do not always realize that the analysis of lime can help with the interpretation. Furthermore, there are still many contradictions about the reasons why lime is applied to burials, and the actual effect this chemical has (1).

In the Greek and Roman period, it was a commonly held belief that lime could be used to enhance the speed of decay, to reduce the likelihood of detecting a body, to destroy evidence and that ultimately lime will lead to the rapid and total destruction of human remains (2). To date, this misinterpretation still exists. Other reasons why lime is applied to burials are based on

${ }^{1}$ Laboratoire PACEA De la Préhistoire à l'Actuel: Culture, Environnement et Anthropologie UMR 5199, Université de Bordeaux, Bat. B8, Allee Geoffroy St Hilaire, CS 50023, 33615, Pessac Cedex, France.

${ }^{2}$ Department of Archaeological Sciences, University of Bradford, West Yorkshire BD7 1DP, UK.

${ }^{3}$ Unit of Physical Anthropology, Department of Biology, Universidad Autónoma de Madrid, C/Darwin 2, Madrid 28049, Spain.

${ }^{4}$ Department of Physical Anthropology, Aranzadi Society of Sciences, Zorroagagaina 11, Donostia, Basque Country, Spain.

${ }^{5}$ Department of Chemistry, University of Bradford, West Yorkshire BD7 1DP, UK

${ }^{6}$ School of Chemistry, University of Lincoln, Lincoln, LN6 7DL, UK.

${ }^{7}$ Department of Paleobiology, National Museum of Natural Sciences (MNCN-CSIC), José Gutierrez Abascal 2, 28006 Madrid, Spain.

*Funding provided by the French State to co-author Schotsmans in the frame of "Investments for the future" (IdEx Bordeaux ANR-10-IDEX-0302), and financial support provided to co-author Rios by the Spanish Ministry of Economy and Competitiveness (CSO2012-32709).

Received 18 Sept. 2015; and in revised form 14 May 2016; accepted 28 May 2016. the assumption that it reduces putrefactive odours or could work as disinfectant.

Lime is often observed in clandestine burials (3-12), and in mass burials and single graves associated with conflict, including World War I $(13,14)$, World War II $(15,16)$, the Spanish Civil War (17-19), the Portuguese Colonial War (20), or in relation to the conflicts in former Yugoslavia (21). Furthermore, lime can be associated with burials of victims of natural disasters, such as tsunamis or earthquakes (22), with disease (23-26), and with animal disposal (27-29).

Lime, derived from limestone (calcium carbonate $\mathrm{CaCO}_{3}$ ), is a generic term used to cover calcium oxide $(\mathrm{CaO}$ variously known as quicklime, unslaked lime, or burnt lime), calcium hydroxide $\left(\mathrm{Ca}(\mathrm{OH})_{2}\right.$ variously known as hydrated lime or slaked lime), and nonpure derivatives such as hydraulic lime. Lime can be made from limestone of both the calcite polymorph and the aragonite polymorph. When limestone is calcined at a temperature in excess of $800^{\circ} \mathrm{C}$, carbon dioxide $\left(\mathrm{CO}_{2}\right)$ evolves, resulting in a white residue of calcium oxide or quicklime $(\mathrm{CaO})$. Calcium oxide is extremely hygroscopic. It absorbs atmospheric moisture rapidly or reacts strongly with liquid water in a process of hydration. When water is added to quicklime, an exothermic reaction takes place to form calcium hydroxide. This can yield a dry, powdery product or, when lime slaking occurs with an excess of water, it produces a slurry of hydrated lime. Calcium hydroxide has the property to harden in reaction with carbon dioxide, a process called carbonation. On exposure to air, reabsorption of carbon dioxide by hydrated lime occurs and water is driven off, resulting in the formation of calcium carbonate once again. The difference between quicklime and hydrated lime is difficult to make because, even if quicklime is not hydrated on purpose, it reacts rapidly with atmospheric moisture or moisture from the depositional environment to convert to hydrated 
lime (1,30-32). Therefore, authors have to be cautious to conclude that "quicklime" was added to the grave (18).

Lime is an alkaline product $(\mathrm{pH} \mathrm{12-14).} \mathrm{It} \mathrm{is} \mathrm{used} \mathrm{in} \mathrm{leather}$ tanning processes where it has a depilatory effect (33). Contact with lime can cause several types of skin reactions from mild irritation to full thickness burns (34). Furthermore, lime is applied in agriculture to raise the $\mathrm{pH}$ and thereby reduce the acidity of soils. Because bacteria operate best within an optimal $\mathrm{pH}$ range, the addition of lime to soils will optimize the bacterial breakdown of organic matter (35). This supports the common belief that covering a body with lime will lead to its rapid decomposition, but the greater the departure from these conditions of optimal $\mathrm{pH}$, the less the bacterial activity will be. If the soil is too alkaline, bacteria will not flourish. For this reason, lime has often been used as a disinfectant in carcass disposal and during mass disasters. However, the World Health Organization (WHO) specifically advises against the use of lime as disinfectant because of its limited effect on infectious pathogens. Instead, the WHO recommends use of chlorine solutions or other medical disinfectants $(22,36,37)$.

Schotsmans et al. studied the actual effects of lime on decomposition (30-32). The results showed that lime retards the rate of decomposition if present in a burial environment, but does not stop it. As lime is only applied to the outside of a body, putrefactive decay continues from the inside by microorganisms derived mainly from the body itself. Bacterial populations on the exterior of the carcass are reduced by the lime, but not eliminated. A superficial desiccation takes place, but the surface area to volume ratio is too large to desiccate a full body with internal organs and bacterial community. The end result is skeletonization (30-32). In history, it is therefore not surprising that visceral organs were removed during artificial mummification since remains deteriorate from the inside outwards subject to bacterially driven putrefaction (38-41). Besides disinfection, various sources suggest the use of lime to reduce putrefactive odours and discourage scavenging by predators. Schotsmans et al. noticed that lime acts as a sink and buffers the decay gases (31). Another publication on odours and lime suggests that lime is only effective at reducing an initial odour within the first few weeks postmortem (42).

\section{Spanish Civil War}

In Spain, in July 1936, after a coup lead by a group of fascist military officers, a civil war was fought between Republicans, loyal to the established Spanish Republic, and the so-called Nationalists, led by General Franco, who subsequently won the war and established a dictatorship that lasted until his death in 1975. It has been estimated that during the Civil War (19361939) and the first years of the dictatorship that followed, at least 170,000 people were victims of extrajudicial executions, court-martials, and popular tribunals; approximately 130,000 people were victims of Nationalist violence, and 39,000 persons were victims of Republican violence $(43,44)$. Most of these victims were buried in mass graves in the countryside and at cemeteries (for a description of the term "cemetery" during the Spanish Civil War, see Congram (45)).

Graves of the victims of Republican violence were exhumed during the 1940s with support of the dictatorship, while mourning or commemoration of victims of the Nationalist violence was prohibited $(46,47)$. The political context of the transition to democracy in Spain included a pact of oblivion of human rights violations inflicted during the civil war and dictatorship $(48,49)$.
In the late 1970 s and early 1980 s, relatives of the victims of Nationalist violence proceeded to the exhumation of the graves themselves without support of the state (50). In 2000, this situation changed and relatives of victims of Nationalist violence requested the intervention of professionals in forensic sciences including archaeologists, anthropologists and forensic pathologists for the exhumation and identification of the human remains from the mass graves (51). Since 2000 and at the request of relatives of the victims, at least 357 grave excavations have been carried out, with a total of 6288 remains recovered (52). Results of the identification processes are reported by Rios et al. $(53,54)$ and Etxeberria et al. (55). In addition, the graves provide a wide range of archaeological, historical, osteological, and taphonomic information $(17-19,56)$.

\section{Cemetery of la Carcavilla}

The former Old Town Cemetery of La Carcavilla, now converted into a park, is located in the city of Palencia (Spain) and was in use from the mid-19th century until 1955. Within $48 \mathrm{~h}$ after the 18 July 1936 army coup, its supporters took control of the city of Palencia and the whole province. Trade unionists and members of left political parties were arrested and arbitrarily executed by extreme right wing paramilitary garrisons until midAugust 1936. Then, the army took control and a period of fraudulent court-martials began, trials which frequently ended in death penalties (57). According to estimations of historians, based on local and national archives, the number of victims of Francoist repression in the province of Palencia reached 1322 individuals. They were mostly victims of extrajudicial executions, and many of them were executed following fraudulent court-martials without due process (hereafter called victims of court-martials) $(58,59)$. Between July 1936 and February 1938, over 500 victims of extrajudicial executions and death penalties issued by court-martials were buried in the cemetery.

At the request of associations representing the relatives of the victims, excavations were carried out during two field seasons in 2009 and 2011. The sole objective of the forensic project was to exhume the remains of victims of the Civil War. A total of 154 graves were excavated, classified in three categories (Fig. 1, Table 1): (1) single inhumations and mass graves with victims of the Civil War (SIMG), (2) reused graves (RG) (graves that originally belonged to the first category but were reused afterward), and (3) conventional burials (CB). These categories, detailed below, were based on the combination of documentary, archaeological, and anthropological evidence (Fig. 1).

La Carcavilla has a long history of human occupation. During the forensic excavation at La Carcavilla cemetery, evidence for occupation during the Roman period was found, based on ceramic analysis of terra sigillata (second half of the first century) (60). Historical records date the last occupation of the site to 1852. The archaeological team found evidence of a burial of an individual wearing a uniform of the Royal Spanish Guard, an Infantry Corp of King Carlos IV who reigned between 1788 and 1808. Because of this long period of human occupation, the geochemical context of the site has been classified as anthropogenic soil. The $\mathrm{pH}$ of soil samples obtained from unlimed as well as limed burials ranged between $\mathrm{pH} 7.7$ and 8.6. No distinctive $\mathrm{pH}$ differences were observed between limed and unlimed graves. All samples contained a low proportion of organic matter and a high proportion of calcium.

All excavated human remains were completely skeletonized. However, skeletal preservation was diverse. Clear differences 


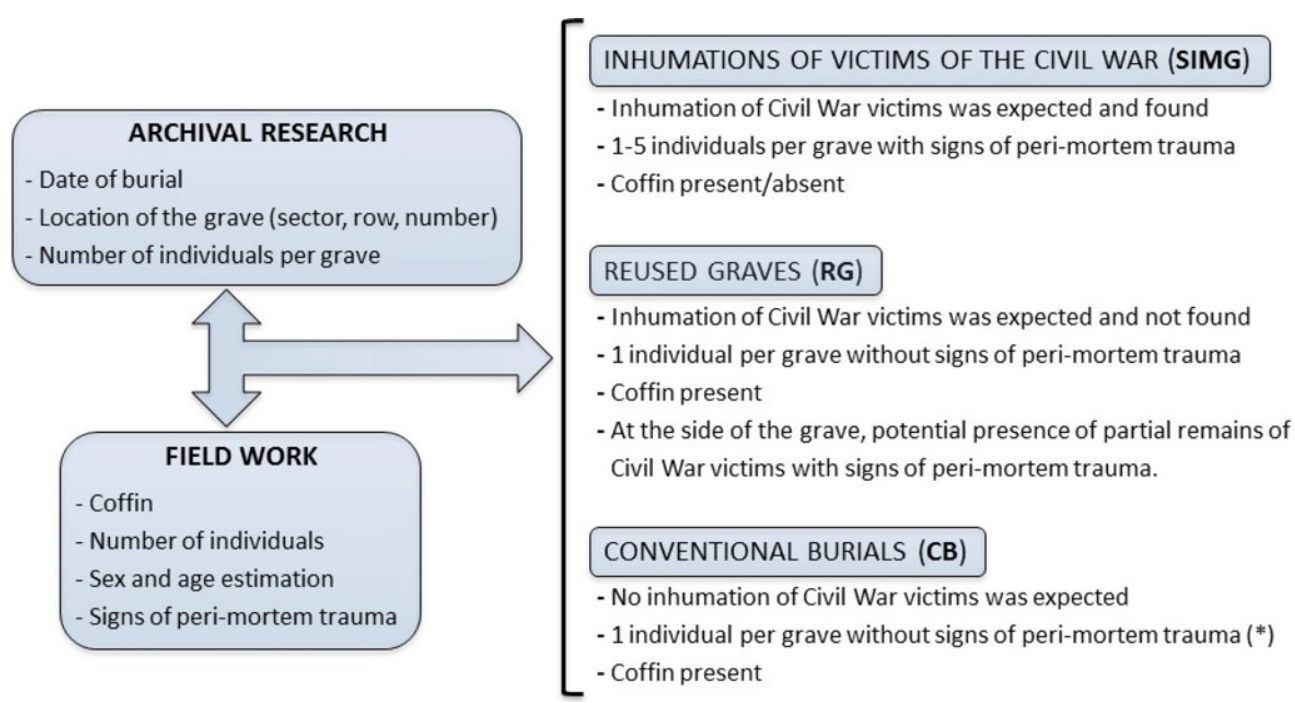

FIG. 1-Based on archival research and archaeo-anthropological information in the field, the burials at La Carcavilla cemetery were classified in three categories: single inhumations and mass graves with victims of the Civil War (SIMG), reused graves $(R G)$, and conventional burials (CB). (*): One conventional burial was a potential double interment (see text and Fig. 4). [Color figure can be viewed at wileyonlinelibrary.com]

TABLE 1-An overview of the burials at the cemetery of La Carcavilla. The presence of lime is indicated together with the presence or absence of a coffin. (*) Among the conventional burials, there are 33 skeletons as burial 6610 is considered as a double inhumation.

\begin{tabular}{|c|c|c|c|c|}
\hline & & & Graves & $\begin{array}{l}\text { Total no of } \\
\text { individuals }\end{array}$ \\
\hline \multicolumn{5}{|c|}{ Graves with victims of the civil war } \\
\hline \multirow[t]{4}{*}{ Single } & Coffin & Lime & - & - \\
\hline & & No lime & 8 & 8 \\
\hline & No coffin & Lime & 6 & 6 \\
\hline & & No lime & - & - \\
\hline \multirow[t]{4}{*}{ Double } & Coffin & Lime & 3 & 6 \\
\hline & & No lime & 1 & 2 \\
\hline & No coffin & Lime & 2 & 4 \\
\hline & & No lime & - & - \\
\hline Triple & No coffin & Lime & 15 & 45 \\
\hline Quadruple & No coffin & Lime & 8 & 32 \\
\hline Quintuple & No coffin & Lime & 1 & 5 \\
\hline Total & & & 44 & 108 \\
\hline Reused gra & & & 78 & 78 \\
\hline Convention & ials & & 32 & $33^{*}$ \\
\hline Total & & & 154 & 218 \\
\hline
\end{tabular}

were observed between coffined burials without lime in which the preservation ranged from very poor to good, and in limed graves without coffins which revealed well-preserved skeletal material. Remnants of garments and personal effects were recovered with most of the textiles badly preserved or totally degraded with the exception of shoe soles.

\section{Single Inhumations and Mass Graves with Victims of the Civil War (SIMG)}

As mentioned above, victims who were executed following court-martials and victims of extrajudicial executions were interred in the cemetery of La Carcavilla. Graves were located, based on testimonies of the families, cemetery archives, and additional information obtained during the excavation of the burials (Fig. 1). In total, 44 graves containing 108 individuals corresponding to victims of extrajudicial executions and executions following court-martials were exhumed (Table 1). The number of individuals per grave ranged from one to five (Table 1, Fig. 2).

\section{Reused Graves}

Reused graves (RG) consisted of interments of victims of executions that were later used as conventional burials (Fig 1, Table 1). Based on archival research, the archaeologists expected to find the remains of victims of executions. Instead, they discovered conventional, single burials in wooden coffins. Further research of the regulations of the cemetery confirmed the reuse of graves. These documents state that when an interment was not paid for, the remains could be exhumed after 5 years and the grave could be reused as a conventional burial. A total of 78 single coffin inhumations without lime, have been interpreted as the reused graves, which originally contained victims of executions. After careful excavation of the limits of those burials, bone fragments and parts of articulated skeletal remains were found in 29 of these interments (Fig. 3).

\section{Conventional Burials}

Conventional burials (CB) were classified as standard interments resulting from natural mortality, displaying a single inhumation in a wooden coffin, except for grave 6610, a burial with two superimposed individuals and the remnants of two coffins (Fig. 4) (detailed below). After the first unexpected findings of reused graves, the archaeological team decided to extend the excavation to all burials in the large sectors of the cemetery in order to obtain a clear picture of its spatial and temporal organization. Conventional burials were thus excavated, and the skeletal remains were exposed for limited anthropological analyses in situ (sex and age estimation). The basic biological profile was compared to antemortem data from the individual listed at that specific location in the cemetery archives. When it was confirmed that the burial did not correspond to a victim of the Civil War, the skeletal remains were not transported to the laboratory for further analysis. 


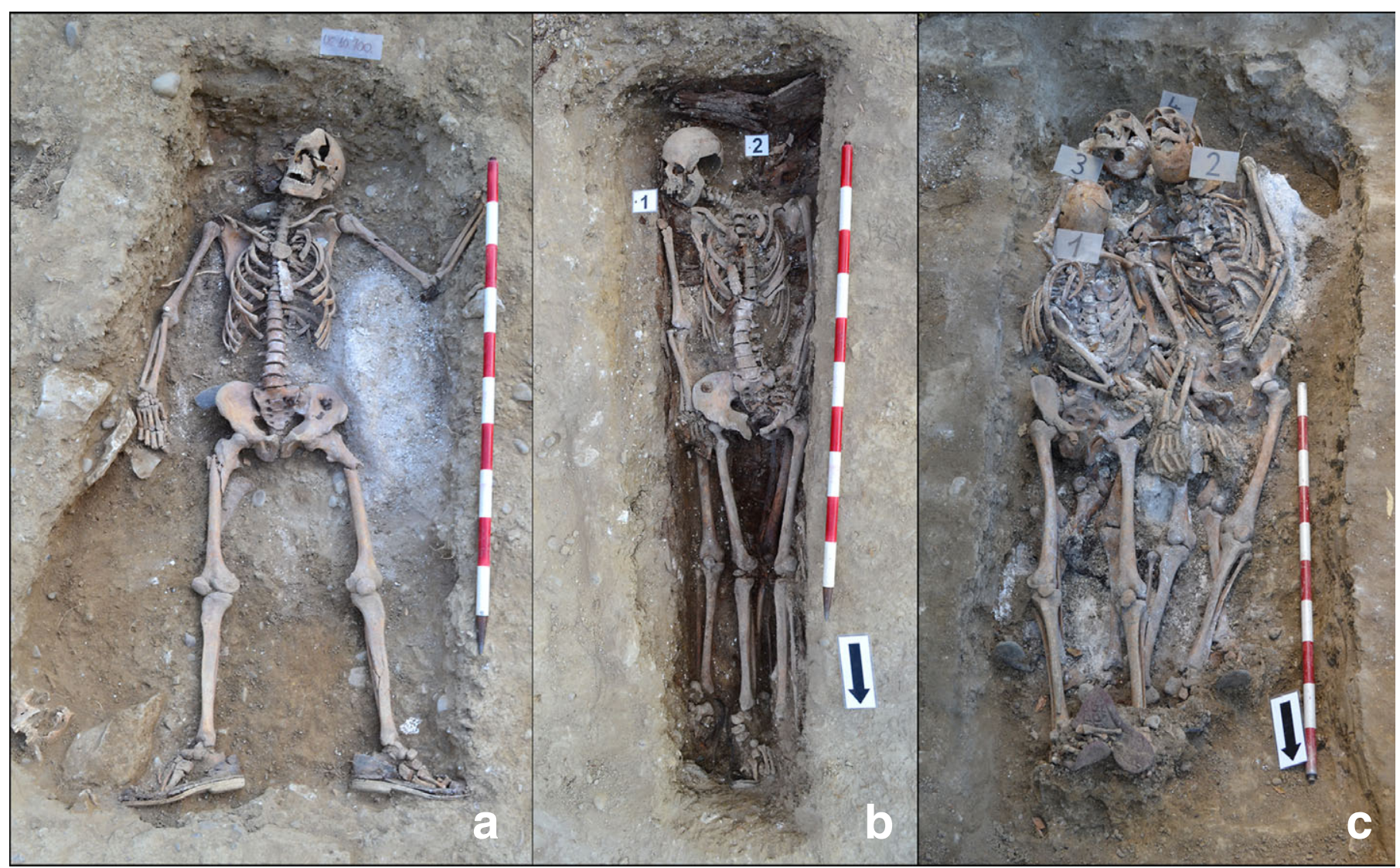

FIG. 2-Interments of victims of court-martials at the cemetery of La Carcavilla. (a) Single burial without coffin and presence of lime. (b) Double inhumation with coffins and lime. Most of the lime was removed during cleaning of the skeletons for the photograph. Remnants of lime can be observed in thoracic and lumbar regions. (c) Limed quadruple burial containing four skeletons. [Color figure can be viewed at wileyonlinelibrary.com]

\section{Lime Analysis from La Carcavilla}

\section{Use of Lime at the Cemetery}

The distribution of the use of lime in burials from La Carcavilla is presented in Table 1. With regard to the graves with Civil War victims, SIMG, single inhumations were documented in 14 graves: eight unlimed burials with coffins and six limed burials without coffins (Fig. 2a). Six double inhumations were exhumed consisting of three limed burials with coffins (Fig. 2b), one unlimed burial with coffin, and two limed burials without coffin. The multiple graves containing three to five individuals were always limed and never displayed a coffin (Fig. 2c). The formation of a lime cast (as displayed in Fig. $7 d$ ) was discovered in three graves $\left(n^{\circ} 6220,6300\right.$, and 13,210) with three victims in each burial (Fig $5 a, b)$, and in one grave $\left(\mathrm{n}^{\circ} 6520\right)$ containing the remains of one person (Fig. 5c). Grave 13,210 is discussed below (Fig. 7). It is interesting to note that the lime cast of burial 6220 showed preserved imprints of the clothing worn by the last cadaver that was placed in the grave (Fig. 6).

Concerning the reused graves (Fig. 3, Table 1), 29 of 78 interments consisted of bone fragments and articulated skeletal body parts with peri-mortem trauma. The use of lime associated with those former inhumations was evidenced in eight burials. According to archaeological findings and archival information, these eight burials corresponded to one single, three double, two triple, and four quadruple inhumations.

With regard to the conventional burials, lime was only observed in one interment, the aforementioned grave 6610
(Fig. 4). Field observations showed that the lower skeleton was an adult male over 40 years old. The remains of the upper individual belonged to an adult female over 40 years old. The burial contained a cranial vault that was completely cut, suggestive of a craniotomy as part of a presumed autopsy procedure, but it could not be associated with certainty to one of the individuals. No evidence of antemortem or peri-mortem pathological conditions was observed in either set of human remains.

\section{Materials: Burial 13210}

To illustrate the use of lime in the graves of La Carcavilla cemetery, burial 13,210 is discussed in more detail (Fig. 7). Burial 13,210 displayed an abundance of white powder which had formed a cast over some of the body parts (Fig. $7 d$ ). The grave contained three male individuals. Two of them had an estimated age below 32 years, based on the state of maturation of the sternal epiphysis of the clavicles (61). The third individual ranged between 21 and 46 years based on the Suchey-Brooks system for the pubic symphysis (62). Two of the remains displayed entry and exit gunshot wounds on the cranium. No visible perimortem trauma was observed on the third skeleton whose cranium presented postmortem damage and absence of facial and posterior regions.

Information from testimonies and archives indicated that on 20 August 1936, eight men from the town of Aguilar de Campoo were executed following court-martials, and buried in four graves at La Carcavilla. The graves consisted of two single and 

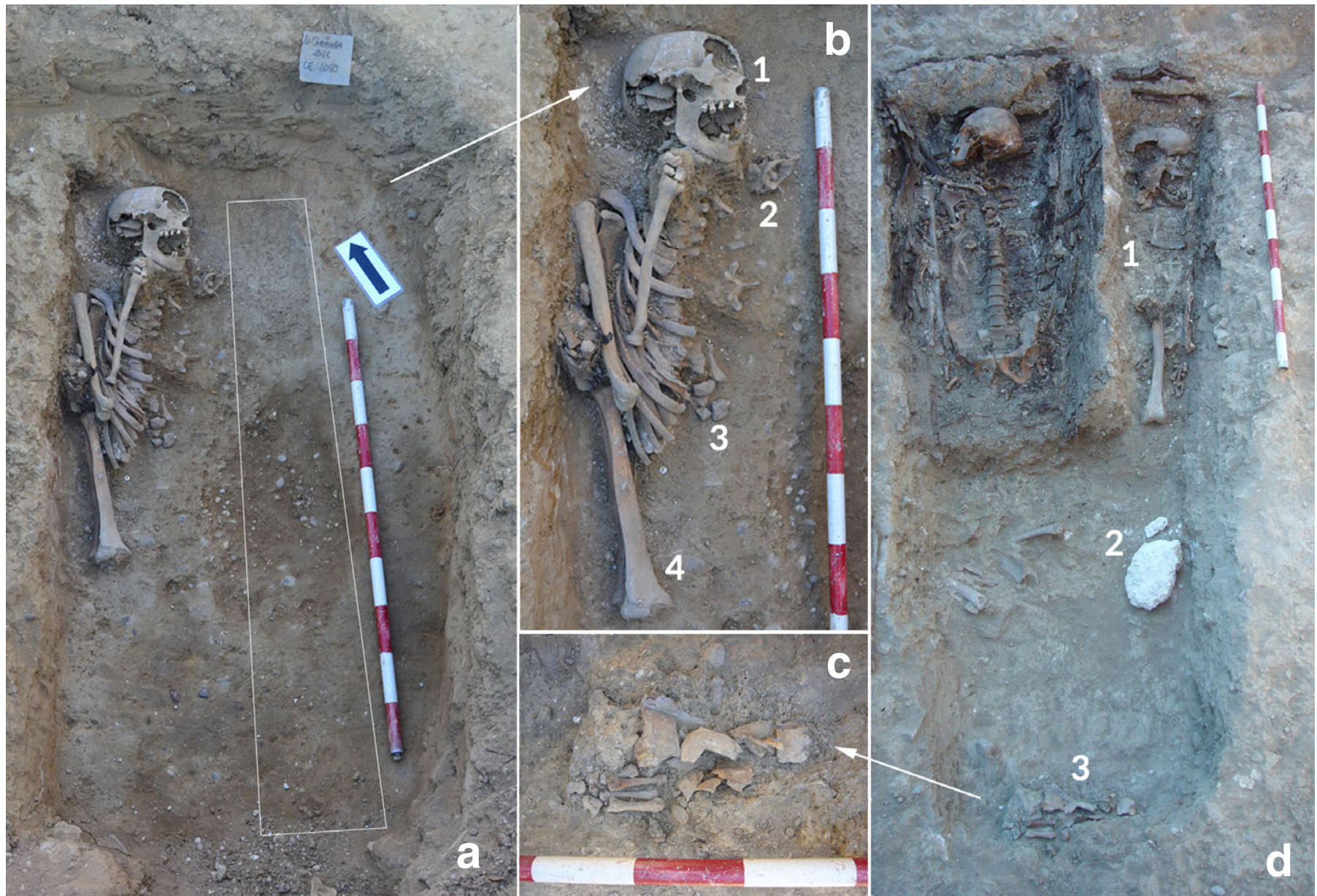

FIG. 3-Two examples of reused graves (RG). (a) Grave 6080 should have contained four Civil War victims according to archival information. However, one unlimed single coffin burial was found, represented by the white rectangle. The soil underneath the coffin was further excavated (see mark in the middle of the rectangle), but this appeared to be the original soil. Subsequently, the excavation was extended to the sides of the coffin and the limits of the original Civil War burial were exposed. At the western side of the grave, the human remains of the four victims were discovered (left). (b) Close-up of the human remains in burial 6080 (a) with remains of four individuals. In situ: 1, cranium with signs of peri-mortem trauma, thorax and right arm of one skeleton; 2, articulated atlas and axis representing a second skeleton; 3, foot bones representing a third skeleton; 4, tibia, fibula, and foot with shoe representing the fourth skeleton. Further laboratory analysis confirmed that these body parts belonged to four different individuals. Remnants of lime can be observed around the cranium. (d) Grave 6670 should have contained four Civil War victims according to archival information, but only one unlimed single coffin burial was found. The excavation was extended underneath the coffin and to the sides of the coffin where remains of the previous Civil War grave were found. 1, an unlimed single coffin burial; 2, large pieces of lime; and 3, partially articulated human remains. (c) close-up of a partially articulated hand (carpals and metacarpals) and cranial fragments with peri-mortem fractures from the original Civil War grave. [Color figure can be viewed at wileyonlinelibrary.com]

two triple burials. Grave 13,210 was one of the triple graves. Based on archival information, testimonies and additional archaeological and anthropological data, the four graves could be localized in the third row of the cemetery. The subsequent identification process through targeted DNA typing allowed identification of at least one individual in each of the four graves, corresponding to the group from Aguilar de Campoo.

\section{Methods}

To confirm that the white powder was lime and to characterize the material, three white powder samples were collected at the side of the right ulna and radius of one of the bodies: One sample was taken from the external surface of the cast (upper side in contact with soil), another sample was collected at the core of the cast, and a last sample was obtained from the inner surface of the cast (the contact side). The samples were analyzed with Raman spectroscopy and powder X-ray diffraction (PXRD). The Raman technique has been found to be applicable for the analysis of lime substrates, gypsum, and mortars (63-65), or the presence of lime in materials (66-69). Furthermore, Raman spectroscopy has a broad application within forensic science (70). Within Raman spectrometry, there are two techniques: dispersive Raman and Fourier transform Raman (FT-Raman). Dispersive Raman usually employs visible laser radiation with typical laser wavelengths of $785 \mathrm{~nm}, 633 \mathrm{~nm}, 532 \mathrm{~nm}$, and $473 \mathrm{~nm}$. A FTRaman spectrometer uses a laser in the near infrared, usually at $1064 \mathrm{~nm}$. The resulting spectral information is essentially the same for both techniques. FT-Raman spectroscopy was developed to overcome some problems occasionally encountered in dispersive Raman spectroscopy. The major advantage of FTRaman lies in the removal or reduction of fluorescence from Raman spectra excited in the visible region of the electromagnetic spectrum. However, in some particular cases, especially in minerals such as calcium hydroxide or hydroxyapatite, this excitation wavelength induces fluorescence bands (71-74) which can be used as a unique diagnostic signature for the forensic identification of the presence of lime and its conversion into calcium 


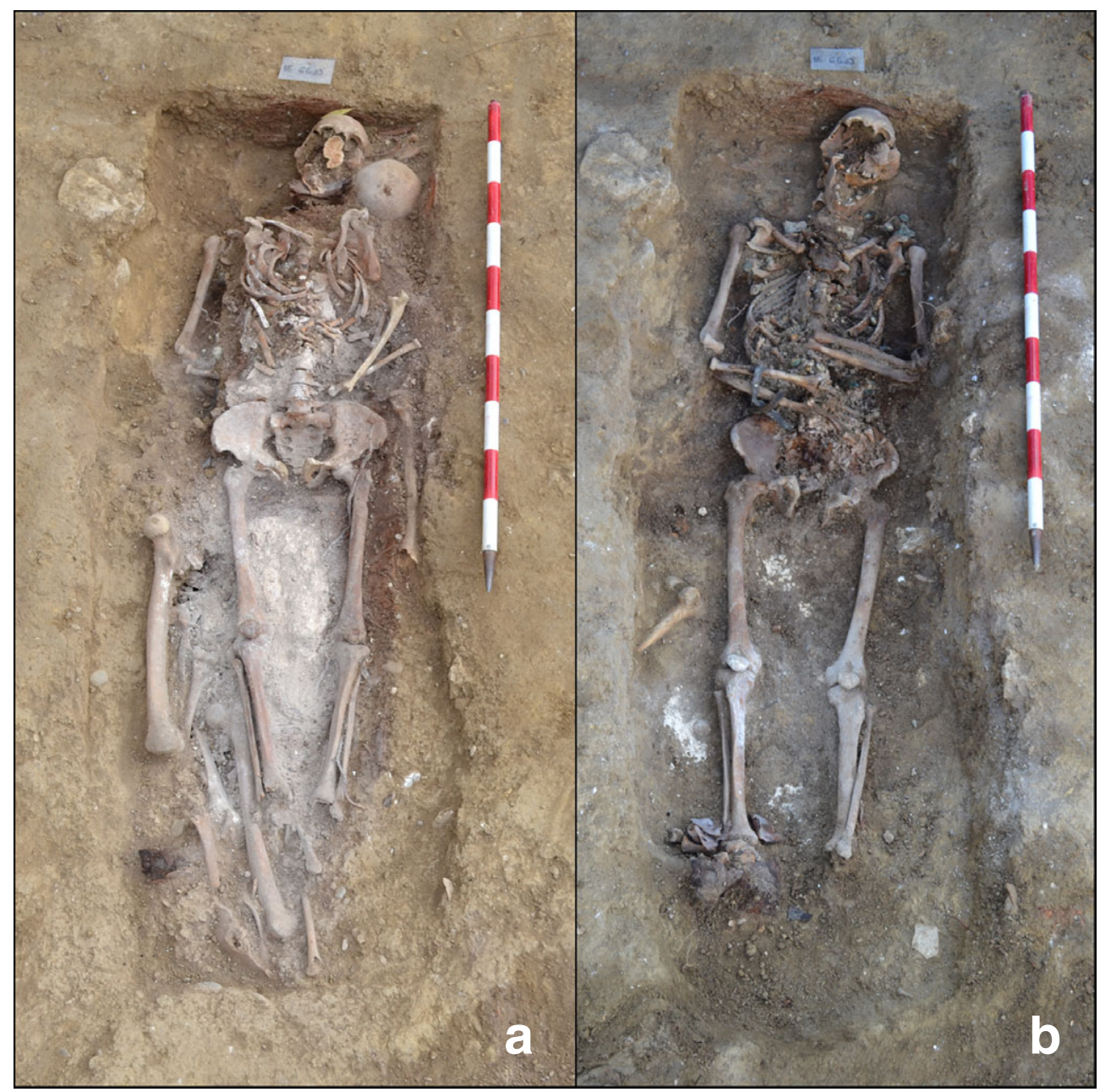

FIG. 4-Grave 6610 at the cemetery of La Carcavilla, displaying two overlying individuals, a possible double inhumation. (a) Two skeletons can be observed, especially at the thoracic and shoulder region: there are two right scapulae. The burial contained a cranial vault, which is a product of a craniotomy (upper right corner). The use of lime was associated with the upper skeleton. (b) In this image, the upper skeleton has been exhumed and the lower individual can be observed. Remnants of wooden coffins were recovered associated with both individuals. [Color figure can be viewed at wileyonlinelibrary.com]

carbonate (65). In respect of hydrated lime, fluorescence bands have proven to be useful as the conversion from calcium hydroxide to calcium carbonate can be measured by the relative Raman intensities of the fluorescence band at $790 \mathrm{~cm}^{-1}$ and the carbonate signal at $1086 \mathrm{~cm}^{-1}(65,68)$. Both Raman and FTRaman are complementary instrumentation.

Spectra were recorded using a Renishaw InVia confocal Raman microscope operating at $785 \mathrm{~nm}$ excitation. The spectral data were scanned for the acquisition of up to 10 accumulations and 10 second laser exposure time with a spectral footprint of about $2 \mu \mathrm{m}$ ( $\times 50$ objective lens).

FT-Raman spectra were recorded using a Bruker IFS 66 infrared spectrometer with an FRA 106 module attachment with $\mathrm{Nd}^{3+} /$ YAG laser at $1064 \mathrm{~nm}$ excitation with a sample spot size of $100 \mu \mathrm{m}$ diameter in macro instrumental mode. Spectra were obtained with 500 co-added scans of data accumulation to enhance the signal-noise ratio and improve the resultant spectra quality. Significant peaks were determined using Grams 8.0 software, ThermoFisher Scientific, and compared with existing laboratory molecular spectral databases for materials identification. In addition, powder X-ray patterns were recorded on a Bruker D8 diffractometer (wavelength of X-rays $0.154 \mathrm{~nm} \mathrm{Cu}$ source, voltage of $40 \mathrm{kV}$, filament emission $30 \mathrm{~mA}$ ). Samples were scanned from 10 to $90^{\circ}(2 \theta)$ using a $0.02^{\circ}$ step width and a $1 \mathrm{sec}$ time count. The receiving slit was $1^{\circ}$ and the scatter slit $0.2^{\circ}$. The powder patterns were evaluated using the EVA software package.

\section{Results}

Dispersive Raman spectroscopy showed a sequence of bands characteristic of calcium carbonate in the calcite form in all samples. A band at $1086 \mathrm{~cm}^{-1}$ is assignable to the symmetric C-O stretching mode of the carbonate ion that at $712 \mathrm{~cm}^{-1}$ is the inplane bending mode and those at 279 and $154 \mathrm{~cm}^{-1}$ are lattice modes (Fig. 8a)

The conversion of calcium hydroxide (hydrated lime) to calcium carbonate can be measured by the relative Raman intensities of the bands at 790 and $1086 \mathrm{~cm}^{-1}$ with FT-Raman spectroscopy. However, if the original calcium carbonate from which the lime was made was in the calcite form, no distinction can be made between the Raman spectrum of the starting material and the reaction product obtained from aerial exposure of hydrated lime and its consequent hardening by re-absorption of carbon dioxide. This was the case with burial 13,210 (Fig. 8b). FT-Raman did not show hydrated lime fluorescence bands in all 


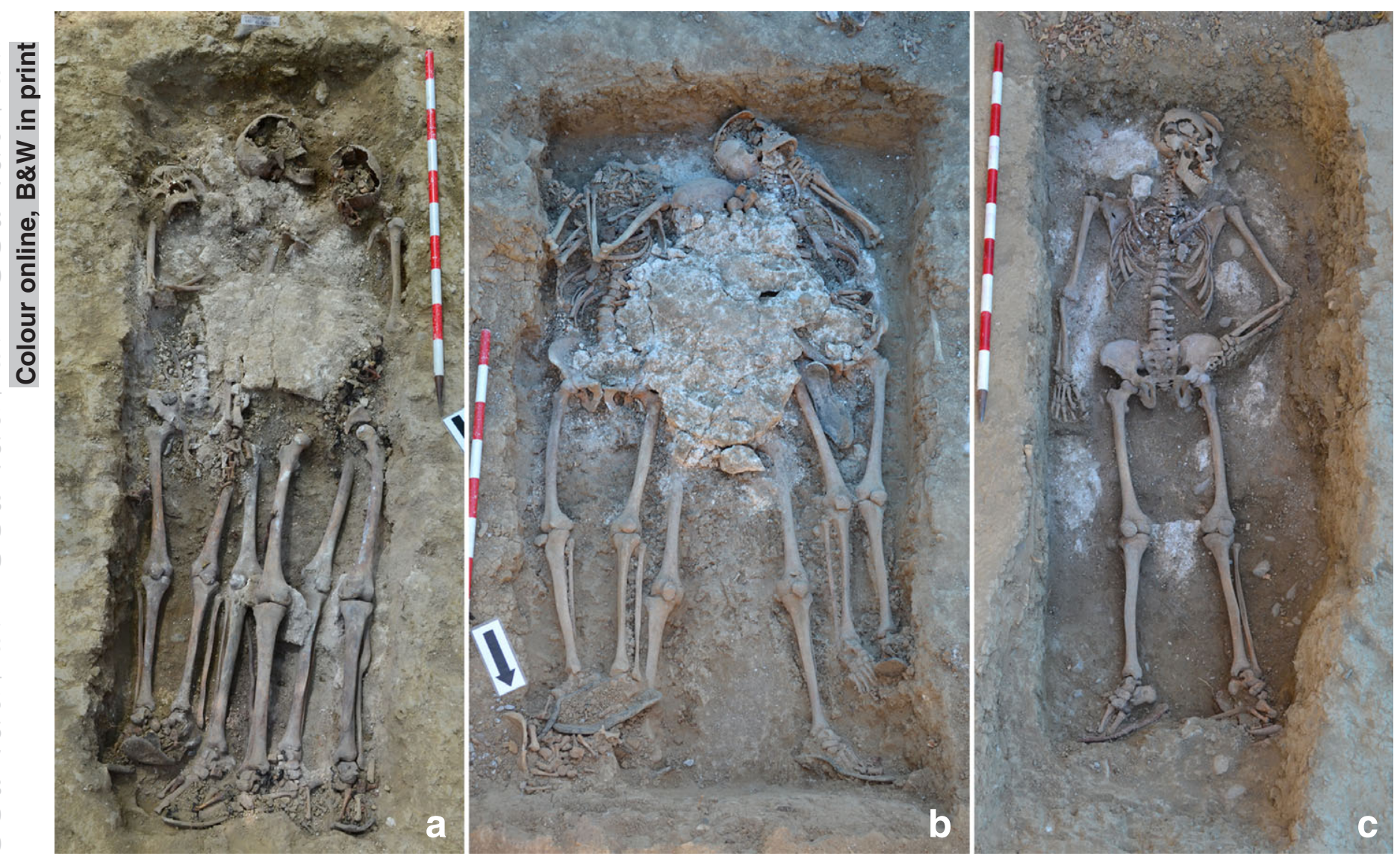

FIG. 5-Limed burials with victims of court-martials. Burial $6300(a)$ and $6220(b)$ are triple interments with collapsed casts of lime, mostly in the thoracic and ventral regions of the skeletons. (c) Burial 6520 consisted of a single, limed inhumation without coffin. A lime cast was formed over the cadaver that partially collapsed over time. The lime was applied after the individual was laid into the grave, creating a silhouette, which can be observed especially in the arms and thorax. [Color figure can be viewed at wileyonlinelibrary.com]

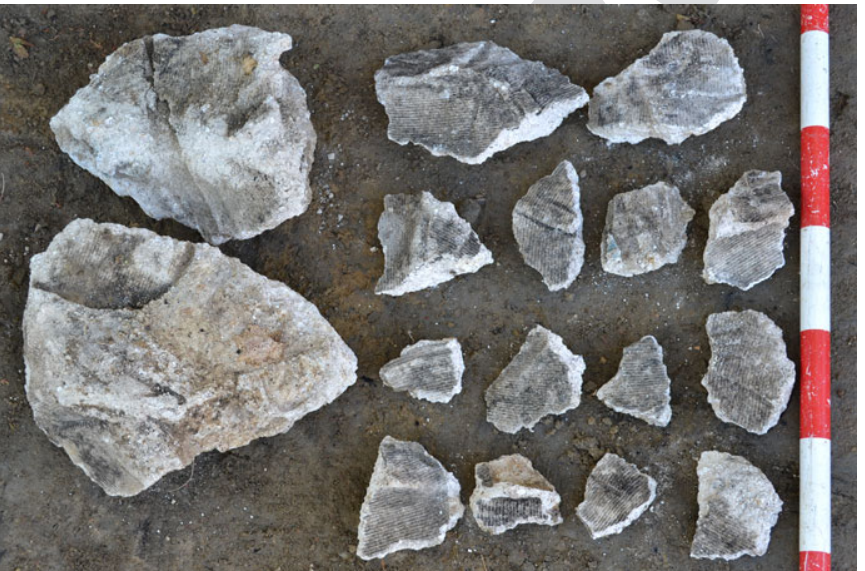

FIG. 6-Parts of the lime cast from grave 6220 (Fig. 5b) with preserved imprints of the corduroy worn by the individual (see text) (Scale: each segment is $10 \mathrm{~cm}$ ). [Color figure can be viewed at wileyonlinelibrary.com]

samples (Fig. 8c). This suggests that the hydrated lime was totally converted into calcium carbonate after a burial period of 70-75 years. The formation of a lime cast confirms this (Fig. 7). Experiments have shown that when lime is applied as a powder, moisture from the soil and decomposing bodies hydrate the lime. Over time the lime hardens and forms a cast in a process called carbonation by reaction with carbon dioxide from the depositional environment (32). It is not always straightforward to make a distinction between the original calcium carbonate (as limestone) and the reaction product of hydrated lime. One could suggest that pure limestone could have been used in the burial. However, in that situation, a cast is unlikely to have formed as solid calcium carbonate is practically insoluble and only effective when processed (75).

Powder X-ray patterns confirmed that the white substance was calcite. The PXRD pattern of the samples contains peaks at $2 \theta=23.1$ (012), 29.4 (104), 31.5 (006), 36.0 (110), 39.5 (113), 43.2 (202), 47.4 (018), 48.6 (116), 56.7 (122), 57.5 (122), 60.8 (214), 64.7 (300) (Fig. 9) and is in good agreement with those reported in the literature for calcite (76).

\section{Interpretation of Lime Burials}

Burial 13,210 contained an abundance of white powder (Fig. 7). It had formed a cast over some of the body parts (Fig. 7d). Observations of the void between the cast and the remains indicated that the formation of the lime cast had occurred, while the victims were still covered with soft tissue (Fig. $7 c, d$ ). This was confirmed by the presence of small remnants of textile in the casts of both arms. Over the years, parts of the cast collapsed. The occurrence of similar lime casts with imprints is noticed in experiments with lime on pig carcasses $(30,32)$. It is not uncommon that imprints of clothing or skin are observed in a cast. Komar et al. describe a forensic case where a 

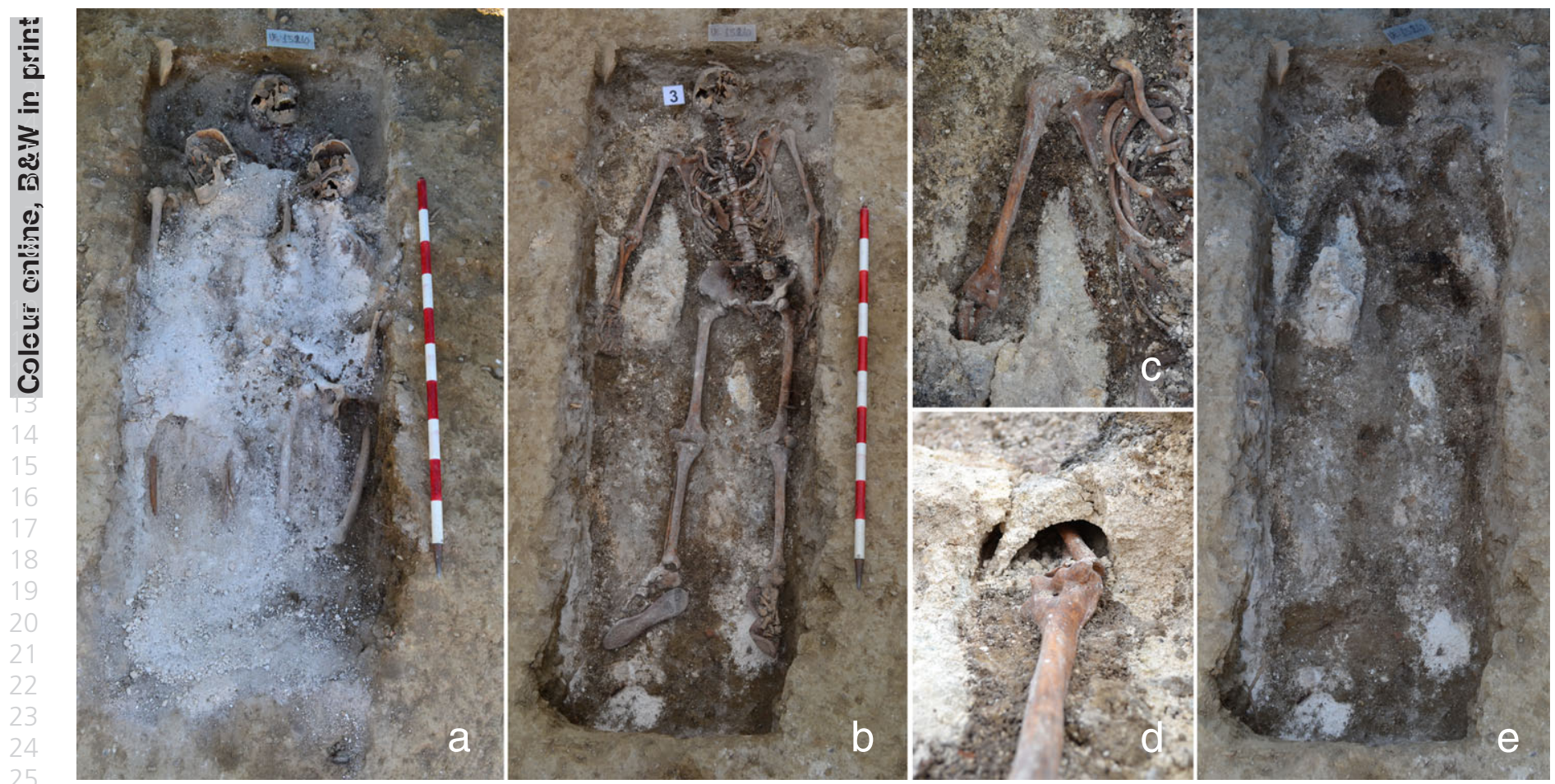

FIG. 7-Grave 13210, in which three victims of court-martials were buried. (a) Photograph of the grave in the initial stage of excavation, a large amount of lime can be observed. (b) Position of the lower skeleton, the first cadaver placed in the grave. (c,d): Silhouette of the right arm and detail of the lime cast formed on the right forearm. (e) Lime applied to the lower cadaver formed a silhouette of the cadaver which could be clearly observed after the recovery of the skeleton. This indicates that lime was applied after the first individual was laid in the grave. [Color figure can be viewed at wileyonlinelibrary.com] $\longrightarrow$

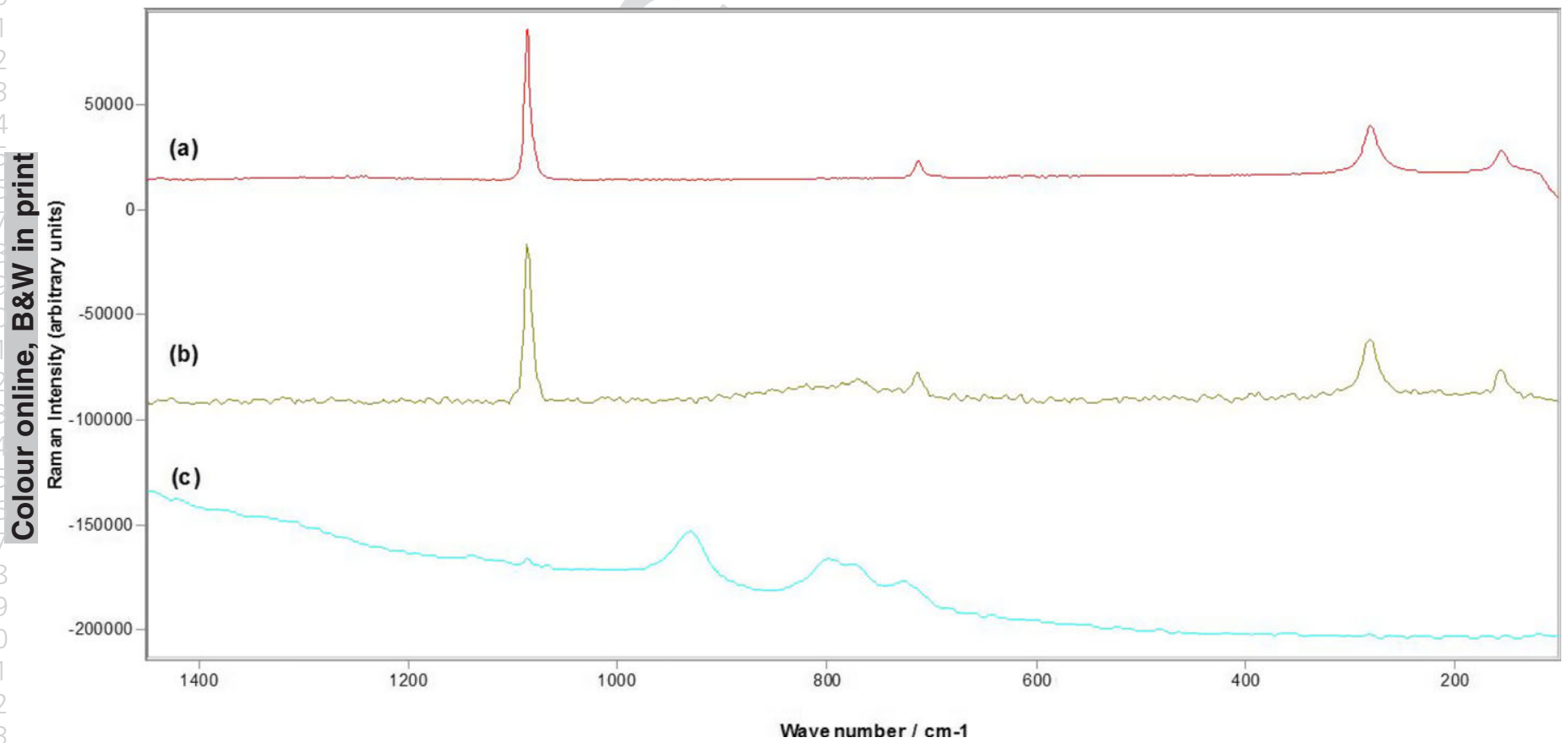

FIG. 8-Raman spectral stack plot of lime from burial 13210 at La Carcavilla cemetery (a-b) and a standard sample of hydrated lime (c). (a) Dispersive Raman spectrum at $785 \mathrm{~nm}$ excitation showing the presence of calcium carbonate in the calcite form with bands at 1086, 712, 279, and 154 cm ${ }^{-1}$. (b) FTRaman spectrum at $1064 \mathrm{~nm}$ excitation displaying just a very small signature of hydrated lime remaining at $790 \mathrm{~cm}^{-1}$ in addition to more intense signals from calcite: suggesting that little hydrated lime remains and most has been converted to calcium carbonate. (c) FT-Raman spectrum at 1064 nm excitation shows a standard sample of hydrated lime displaying fluorescence emission bands around $790 \mathrm{~cm}^{-1}$ indicating that the lime was hydrated (slaked): a very weak signal at $1086 \mathrm{~cm}^{-1}$ is indicative that already a small conversion of the hydrated lime to calcite has commenced by aerial absorption of carbon dioxide. [Color figure can be viewed at wileyonlinelibrary.com]

victim was deposited face down in a grave with lime. The victim's full facial features were captured in the lime revealing a "death mask" (12). Similarly, Congram et al. describe the imprints of the weave of rope and clothing in lime, along with intact buttons of a shirt at the wrist of a limed Civil War victim. Evidence of a rope can indicate that the victim was bound (18). 


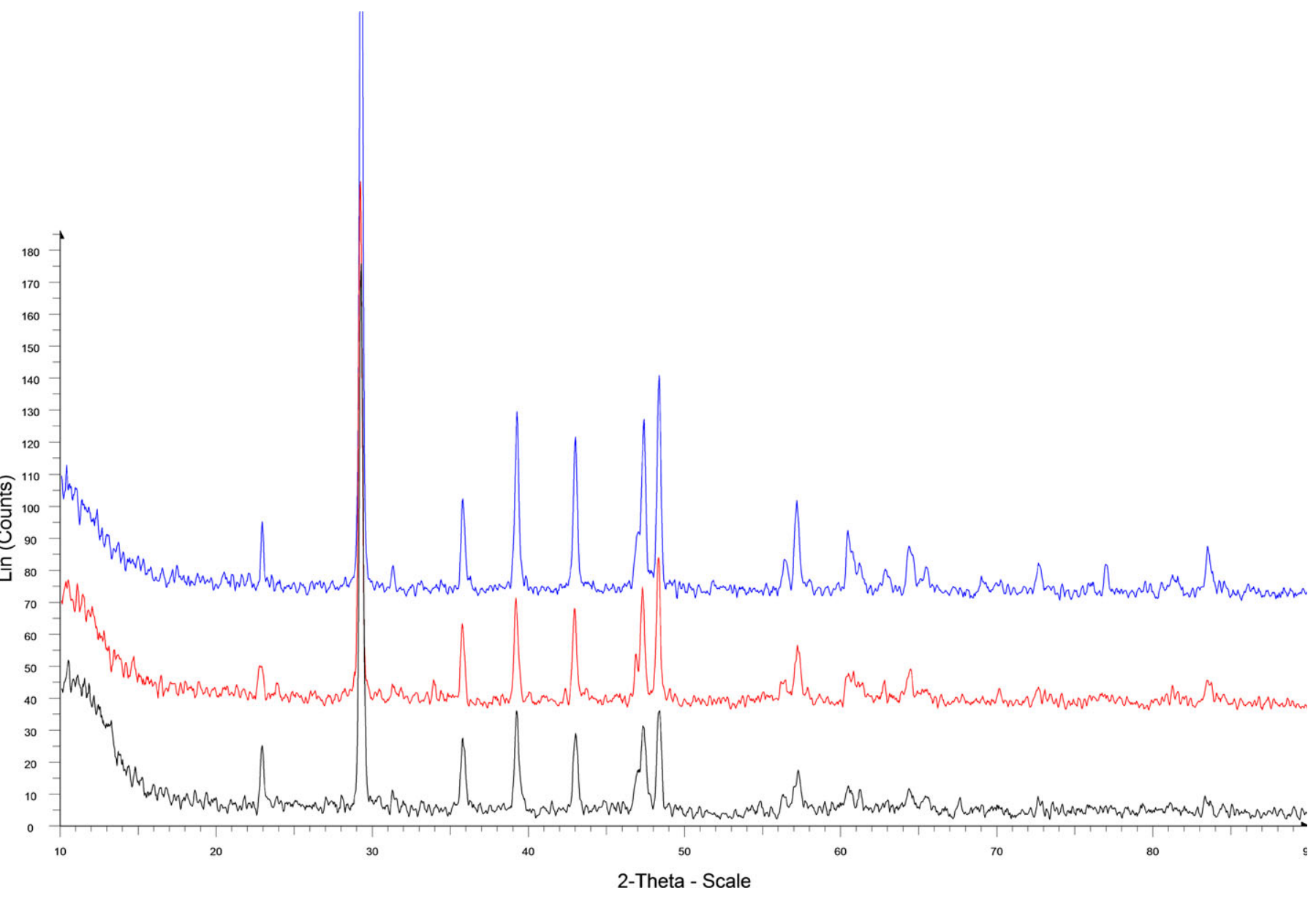

FIG. 9-Powder X-ray patterns of the external surface of the cast (upper), inner surface of the cast (middle), and the core of the cast (lower) showing peaks at $2 \theta=23.1$ (012), 29.4 (104), 31.5 (006), 36.0 (110), 39.5 (113), 43.2 (202), 47.4 (018), 48.6 (116), 56.7 (122), 57.5 (122), 60.8 (214), 64.7 (300), confirmed as calcite. [Color figure can be viewed at wileyonlinelibrary.com]

At La Carcavilla cemetery, triple burial 6220 revealed impressions of a ribbed pattern that corresponds to corduroy (Fig. 6). This fabric is from a warm garment commonly worn by peasants in Spain when it was cold (77). The presence of corduroy corresponds to the date of death of the identified individuals. They were executed following court-martials on 7 Jan 1937 in the middle of the Spanish winter.

It is often thought that the formation of a lime cast is the evident result of pouring liquefied lime over the bodies $(78,79)$. However, experiments have shown that even if lime is applied as a powder, a lime cast can be formed by drawing moisture from its depositional environment (32). As such, by observing lime casts, it cannot be concluded whether lime was poured to the grave in a liquid or powdered state.

Additional interpretations could be made by observing the lime. In burial 13,210, the lime was applied after the first cadaver was laid in the grave. Lime was observed around and on top of the individual but not beneath the skeleton, delineating a silhouette of the cadaver at the bottom of the grave (Fig. $7 b, c, e$ ). After placing the second and third cadaver, more white material was applied. A similar silhouette is observed in burial 6520 (Fig. 5c).

In general, the archaeological findings at the cemetery of La Carcavilla show that the application of lime was used in an organized way. With regard to SIMG, lime was deliberately included in all graves without coffins, ranging from single to multiple interments. Deliberate use of lime was also observed in double inhumations with coffins, with one exception. Interments with more than two remains never contained a coffin and were always limed (Table 1). Lime was not observed in 109 single conventional coffin interments from the same period (78 RG and 31 CB). The exception to the CB was grave 6610, a limed double inhumation with remnants of coffins (Fig. 4).

Information about the application of lime at the cemetery of La Carcavilla was gathered from questionnaires and interviews with the inhabitants of El Cerrato, the rural area where the victims of La Carcavilla lived. The region of El Cerrato, in the province of Palencia, contains an abundance of limestone and gypsum. During the first half of the 20th century, the mining industry provided a cheap supply of lime to the towns of the region through the use of pozo calero (lime kilns), a traditional method for obtaining quicklime from limestone. Lime was considered as communal property with the Town Halls in charge of its storage and supply. The most common use of lime was to whitewash houses, stables, and the interior of churches and hospitals. For example, before the local festivals of the towns, the facades of the houses were usually whitewashed. According to local testimonies, lime was also applied during animal disposal as a hygienic and disinfectant measure and to avoid odors. With regard to human interments, the official regulations of the cemetery of La Carcavilla, approved 9 November 1849, state that the undertaker should apply lime to the graves: "when placing the 
bodies in the grave or niche (...) if in a grave, cover it with a layer of lime for earlier consumption," suggesting that its use was commonly considered to accelerate decay. Based on the testimonies and archival information, it is assumed that the cemetery stored lime.

At La Carcavilla, the use of lime is clearly associated with coffinless interments of Civil War victims (SIMG). This is observed at other cemeteries of the Spanish Civil War. Congram et al. describe eight plain earth multiple-person graves in Uclés (province of Cuenca) which were all limed (18). And at Valdenoceda cemetery (province of Burgos), the Spanish authors of this article (L.R. and A.G.R.) excavated 116 single inhumations of political prisoners who died of illness and starvation. They all contained a coffin and none of them were limed.

A possible interpretation, based on local testimonies which mention the use of lime in animal disposal, is that plain earth inhumations were considered similar to the disposal of dead animals in which lime was applied as a disinfectant to reduce odors. The exact reason for the use of lime could not be explained by the local testimonies.

Observations at La Carcavilla show that lime was not only observed in plain interments, it was also noticed in three of four double inhumations of victims of extrajudicial executions with coffins (Table 1). Clearly, there were two interrelated variables associated with the use of lime: the number of individuals per grave and the presence or absence of a coffin. In the case of the limed double inhumations with coffin, the first variable (number of individuals) outweighs the second variable (presence or absence of a coffin).

Lime was not applied to conventional burials. The absence of lime in conventional burials contradicts the cemetery regulations that stated its use. It is possible that the utilization of lime changed between 1849 and 1930s-1940s, without being reflected in the written regulations. Another option is that the numerous burials of victims of the Spanish Civil War interfered with the routine use of lime in conventional burials. The exception to the conventional burials was grave 6610 , a limed double inhumation in coffin with the upper skeleton displaying a craniotomy. The presence of a craniotomy could indicate that the bodies came from a hospital, and one could think that lime was used as a disinfectant or in relation to orthopedic medical plaster. Orthopedic plaster casts have been observed in interments coming from the Spanish Civil War field hospital of Uclés (18). However, based on experience of one of the authors (L.R.) who excavated in the same hospital cemetery, medical casts are solid structures which preserve well and are easily recognizable in the field. Moreover, during analysis they would not give a calcium carbonate signature but a gypsum signature. That the presence of lime at $\mathrm{La}$ Carcavilla does not directly relate to human remains from a hospital is further supported by three other conventional burials

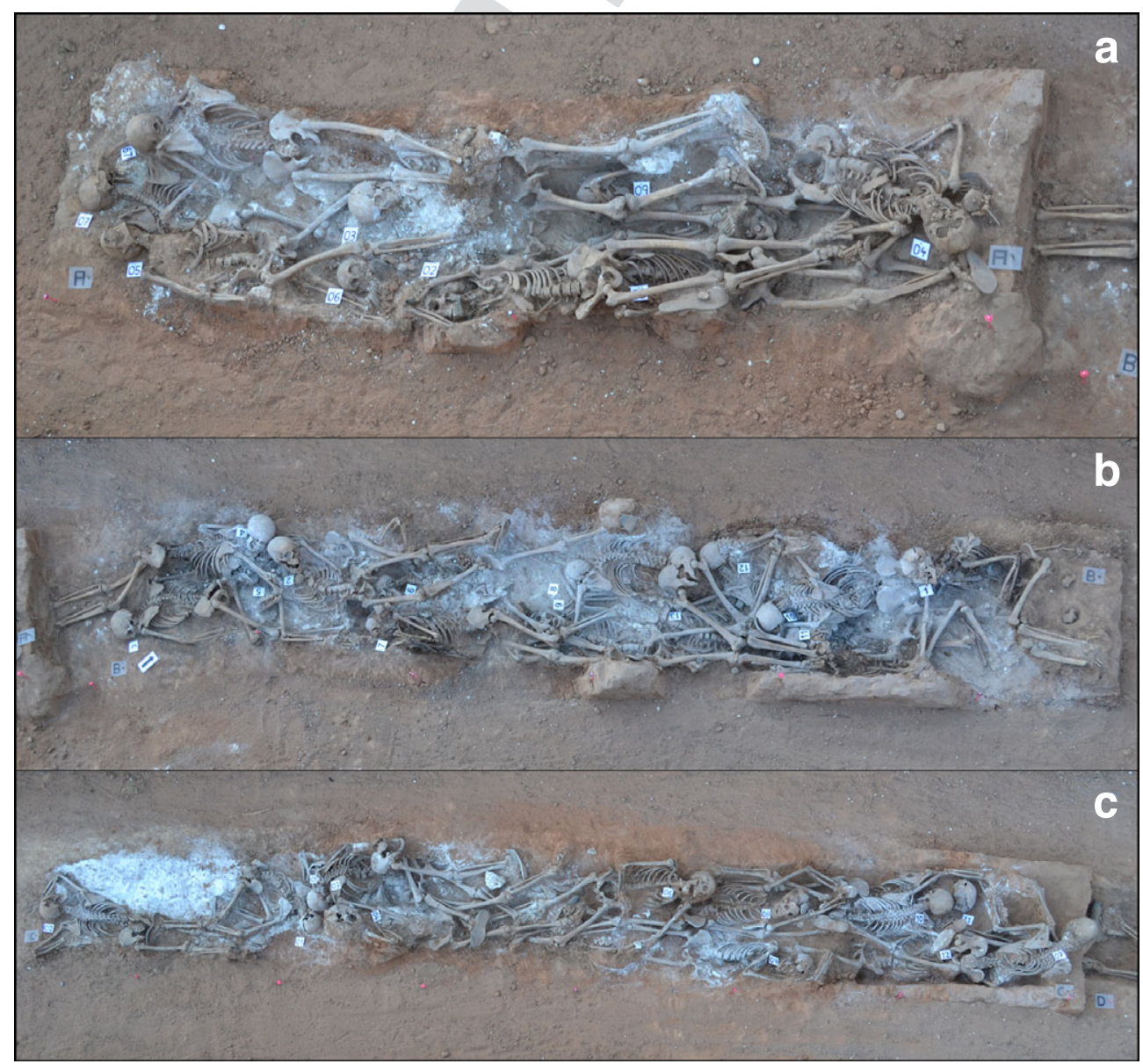

FIG. 10-Excavation at La Legua in Spain, supported by the Aranzadi Society of Sciences. A total of six mass graves, containing 56 skeletons of victims of extrajudicial executions, were excavated inside a $40 \mathrm{~m}$ long ditch located in open countryside. Extensive use of lime can be observed in three of those mass graves, presented in $a, b$, and $c$. Only a part of the ditch was used as burial (approximately $10 \mathrm{~m}$ were empty). The well-organized use of the ditch, together with the extensive use of lime, could indicate premeditation of these large-scale killings. [Color figure can be viewed at wileyonlinelibrary.com] 
from the hospital, in which no lime was observed. One burial consisted of a child, with an amputated right arm, disarticulated left arm and extensive signs of infection. In two other burials, an amputated leg, not belonging to the adult, was found inside the coffin. Often, an amputated limb is transported from the hospital to the cemetery together with the transfer of another dead body. The presence of burials containing only amputated limbs (18) or amputated limbs not belonging to the buried skeleton (field observations by L.R.) was also observed at the hospital burial site of Uclés.

The absence of lime in the three hospital burials of La Carcavilla cannot explain why grave 6610 with craniotomy was limed. It is known that medical students used chlorinated lime to disinfect cadaveric matter during dissections $(80,81)$. But there was no Faculty of Medicine in the city of Palencia, with the nearest one in the city of Valladolid, $50 \mathrm{~km}$ away. Another possible explanation is that lime could have been related to death from contagious disease. This could not be confirmed either. Many acute infectious diseases or epidemics result in death of the infected individual soon after microbial attack without leaving skeletal evidence (82-85). The exact reason of the presence of lime in this conventional burial remains unclear.

The use of lime has also been documented in Spanish Civil War mass graves of victims of executions located in open countryside. In these situations, the documented practice was that victims were first illegally arrested and incarcerated and subsequently released in organized groups of 10-30 persons to be killed and buried in a mass grave covered with lime (Fig. 10) (53). In contrast, a less frequent use of lime was associated with the smaller graves in the countryside containing victims abducted from their houses or work and subsequently killed and buried (Fig. 11) (54). Although these differences are not mutually exclusive, it remains unclear why larger burials were limed and smaller burials were not limed. Both situations were plain earth burials. Was the use of lime related to availability of lime? Or was it thought to be more important to add lime to large mass graves because many corpses in one grave would smell worse, decompose slower or increase the chance of diseases? An additional interpretation is that the use of lime in larger graves is an indication of premeditation for large-scale killings.

\section{Conclusion}

The case study of La Carcavilla indicates that lime, calcium carbonate in the calcite form, was present in several burials. Both limed and unlimed remains were completely skeletonized. This confirms forensic experiments on lime and decomposition $(30,32)$.

In three burials of La Carcavilla cemetery, a cast was formed over the victim's bodies. It is likely that more casts were originally formed but collapsed over time. Lime casts are fragile and their strength depends on various factors including the quantity of lime and the moisture. By observing the cast, it is possible to draw conclusions regarding the absence or presence of soft tissue at the moment of deposition, the presence of clothing or other evidence (sometimes preserved in the cast), and the sequence of events (e.g. body first deposited, then limed). This is also observed by other authors in other limed Spanish Civil War burials (18).

At La Carcavilla, lime was mainly applied to plain earth graves. It is not clear why three double inhumations with coffin were exceptionally limed. Nor could it be explained why the

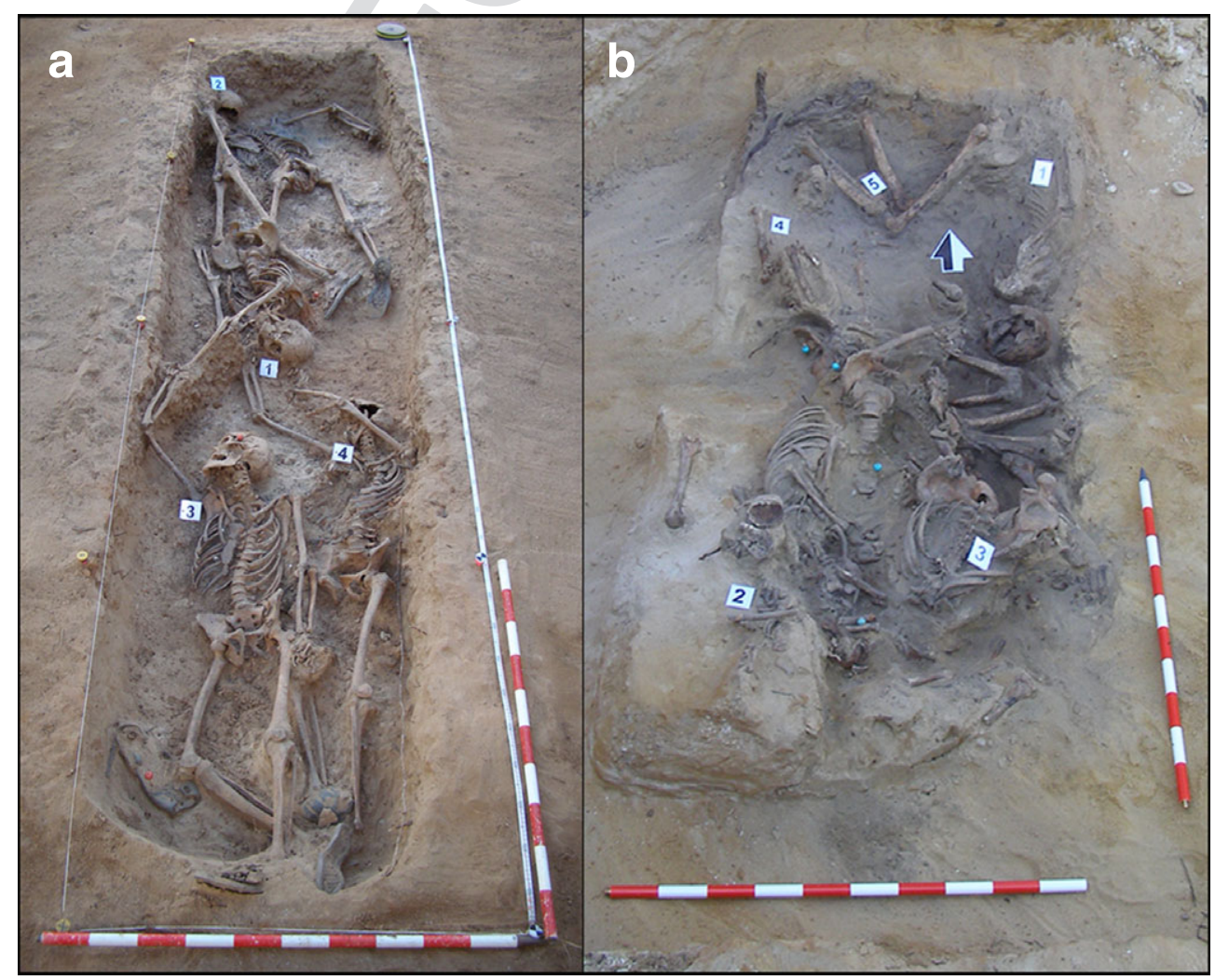

FIG. 11-Images of two mass graves, supported by the Aranzadi Society of Sciences. These graves were located in open countryside and contained the remains of four (a) and five (b) victims of extrajudicial executions. No lime was used in these burials. [Color figure can be viewed at wileyonlinelibrary.com] 
regulations were not followed which state that bodies in a grave or niche should be covered with lime. A key advantage in the interpretation of modern burials from the 20th century is that local people can be interviewed and documentary sources can be consulted. In some cases, survivors or witnesses can testify. However, even with local testimonies in La Carcavilla, many questions remain unanswered regarding the intention of the application of lime. Given the link with animal disposal, it is assumed that lime was mainly used as a disinfectant and against bad decay odors. The possible use of lime to accelerate decay is not excluded either, as the official regulations of the cemetery mention the use of lime "for earlier consumption".

In some cases, the presence of lime can be interpreted as premeditation for killings. In the case of Spanish Civil War-era mass graves, large groups of victims were taken to the countryside, killed, and buried in mass graves covered with lime. The application of lime on such a large scale implies a degree of organization and preparation.

This study has demonstrated that a burial should be analyzed within its taphonomic context. It is clear that important evidence can be revealed by observing the lime and lime cast. Only by publishing more lime burials in the future can these practices be more fully recognized and the effect of lime on human remains might be better understood.

\section{Acknowledgments}

The authors would like to thank all the individuals who participated in the Spanish excavation. A special thanks to Dr. Francisco Etxeberria for the discussion regarding the use of lime in human burials; Manuel Monge, Angel Redondo, and Jose Ignacio Marin for their support on the Spanish site; and Dr. Fernando Serrulla for his help with the soil analysis. We would also like to acknowledge the Department of Chemical \& Forensic Sciences at the University of Bradford (UK) and CRP2A (Centre de Recherche en Physique appliquée à l'Archéologie) at Université Bordeaux Montaigne (FR). We are grateful to Dennis Farwell and Rhea Brettell for their contributions to the sample analyses.

\section{References}

1. Schotsmans EMJ, Van de Vijver K, Wilson AS, Castex D. Interpreting lime burials. A discussion in light of lime burials at St. Rombout's cemetery in Mechelen, Belgium (10th-18th centuries). J Archaeol Sci Rep 2015;3:464-79.

2. Bailey KC. The Elder Pliny's chapters on chemical subjects, part II. London, U.K.: Arnold \& Co, 1932.

3. Hochrein MJ. An autopsy of the grave: recognizing, collecting and preserving forensic geotaphonomic evidence. In: Haglund WD, Sorg MH, editors. Advances in forensic taphonomy. Boca Raton, FL: CRC Press, 2002;45-69.

4. Jones AM. An unusual atypical gunshot wound. Am J Forenic Med Pathol 1987;8:338-41.

5. Jackson S. No stone unturned. The story of Necrosearch International. New York, NY: Kensington Publishing Corporation, 2002.

6. Bass WM, Jefferson J. Death's acre. New York, NY: Putnam, 2003.

7. Jackson ARW, Jackson JM. Forensic science, 2nd edn. Essex, U.K.: Pearson Education Limited, 2008.

8. D'Errico S, Turillazzi E, Pomara C, Fiore C, Monchiotti F, Fineschi V. A novel macabre ritual of the Italian mafia. Am J Forensic Med Pathol 2011;32(1):44-6.

9. Manhein MH. Decomposition rates of deliberate burials: a case study of preservation. In: Haglund WD, Sorg MH, editors. Forensic taphonomy: the postmortem fate of human remains. Boca Raton, FL: CRC Press, 1996;469-82.
10. Laudermilk JD. Concerning quicklime burial. Am J Police Sci 1932;59:59-63.

11. Congram DR. A clandestine burial in Costa Rica: prospection and excavation. J Forensic Sci 2008;53(4):793-6.

12. Komar DA, Davy-Jow S, Decker S. The use of a 3-D laser scanner to document ephemeral evidence at crime scenes and postmortem examinations. J Forensic Sci 2012;57(1):188-91.

13. Jünger E. Storm of steel: from the diary of a German storm-troop officer on the western front. London, U.K.: Penguin Books, 2004.

14. Jankauskas R. Forensic archaeology in Lithuania. In: Groen WJM, Marquez-Grant N, Janaway RC, editors. Forensic archaeology. A global perspective. Chichester, U.K.: Wiley-Blackwell, 2015;99-120.

15. Klug L. Surviving the fire. Mother courage and World War II. Greensboro, NC: Open Hand, 1989.

16. Blumoff TY. The holocaust and public discourse. In: DeCoste FC, Schwartz B, editors. The Holocaust's ghost: writings on art, politics, law and education. Edmonton, Canada: The University of Alberta Press, 2000;212-43.

17. Ríos L, Garcia-Rubio A, Martinez B, Herrasti L, Etxeberria F. Patterns of peri-mortem trauma in skeletons recovered from mass graves from the Spanish Civil War (1936-1939). In: Knüsel C, Smith MJ, editors. The Routledge handbook of the bioarchaeology of human conflict. London, U.K.: Routledge, 2014;621-40.

18. Congram D, Flavel A, Maeyama K. Ignorance is not bliss: evidence of human rights violations from civil war Spain. Ann Anthropol Prac 2014;38(1):43-64.

19. Etxeberria F, Herrasti L, Serrulla F, Marquez-Grant N. Contemporary exhumations in Spain: recovering the missing from the Spanish Civil War. In: Groen WJM, Marquez-Grant N, Janaway RC, editors. Forensic archaeology. A global perspective. Chichester. U.K.: Wiley-Blackwell, 2015;489-97.

20. Cunha E, Ferreira MT, Codinha S, Carmin G, Marques C, Umbelino C. Recovering memories of the Portuguese Colonial War through forensic anthropology. In: Groen WJM, Marquez-Grant N, Janaway RC, editors. Forensic archaeology. A global perspective. Chichester, U.K.: WileyBlackwell, 2015;479-88.

21. International Criminal Tribunal for the former Yugoslavia. Transcripts of expert witnesses in the Krstic trial, IT-98-33, 30 May 2000. The Hague, the Netherlands: ICTY, 2000.

22. De Ville de Goyet C. Epidemics caused by dead bodies: a disaster myth that does not want to die. Pan. Am J Public Health 2004;15:297-9.

23. Jankauskas R, Miliauskiene Z, Kuncevicius A. Palaeopathology of German military hospital remains from 1915-1918. In: Knüsel C, Smith MJ, editors. The Routledge handbook of the bioarchaeology of human conflict. London, U.K.: Routledge, 2014;602-20.

24. Signoli M. Etude anthropologique de crises démographiques en contexte épidémique. Aspects pléo- et biodémographiques de la Peste en Provence. Marseille, France: Université de la méditerranée - Aix-Marseille II, 1998.

25. Castex D, Bruzek J, Sellier P, Veleminsky P, Kucharova H, Bessou M, et al. Bioarchaeological study of a mortality crisis. Cemetery of St. Benedict in Prague, Czech Republic (17th-18th century AD): methodological approach. Anthropology 2011;49(1):79-88.

26. Martin J. The returning casualty: the excavation of a communist re-education camp cemetery at Lang Da, Yen Bai province, Vietnam. In: Groen WJM, Marquez-Grant N, Janaway RC, editors. Forensic archaeology. A global perspective. Chichester, U.K.: Wiley-Blackwell, 2015;507-13.

27. Chin J. Control of communicable diseases manual. Washington, DC: American Public Health Association, 2000.

28. Nutsch A, Spire M. Carcass disposal: a comprehensive review. Manhattan, KS: National Agricultural Biosecurtiy Center, Kansas State University, 2004

29. Bushnell LD, Jackley JG. Poultry diseases. Manhattan, KS: Kansas Agricultural Experiment Station, 1918.

30. Schotsmans EMJ, Denton J, Dekeirsschieter J, Ivaneanu T, Leentjes SC, Janaway RC, et al. Effects of hydrated lime and quicklime on the decay of buried human remains using pig cadavers as human body analogues. Forensic Sci Int 2012;217:50-9.

31. Schotsmans EMJ, Denton J, Fletcher JN, Janaway RC, Wilson AS. Short-term effects of hydrated lime and quicklime on the decay of human remains using pig cadavers as human body analogues: laboratory experiments. Forensic Sci Int 2014;238:142.e1-e.10.

32. Schotsmans EMJ, Fletcher JN, Denton J, Janaway RC, Wilson AS. Long-term effects of hydrated lime and quicklime on the decay of human remains using pig cadavers as human body analogues: Field experiments. Forensic Sci Int 2014;238(141):e1-13. 
33. Reed R. Ancient skins, parchments and leathers. London, U.K.: Seminar Press, 1972.

34. Sherman SC, Larkin K. Cement burns. J Emerg Med 2005;29(1):97-9.

35. Kuhlmann R. Calcium carbonate, a versatile mineral. In: Tegethoff FW, Rohleder JW, Kroker A, editors. Calcium carbonate from the Cretaceous Period into the 21st century. Basel, Switzerland: Birkhäuser, 2001;275-312.

36. World Health Organization. Technical notes for emergencies: disposal of dead bodies 8. Geneva, Switzerland: World Health Organization/Regional Office for South-East Asia, 2005.

37. Healing TD, Hoffman PN, Young SE. The infection hazards of human cadavers. Comm Dis Rep Rev 1995;5(5):61-8.

38. Aufderheide AC. The scientific study of mummies. Cambridge, U.K.: Cambridge University Press, 2003.

39. Brier B. A thoroughly modern mummy. Archaeology 2001;54(1):43-4.

40. Arriaza BT. Beyond death: the Chinchorro mummies of ancient Chile. Washington, DC: Smithsonian Books, 1995.

41. Marquet PA, Santoro CM, Latorre C, Standen VG, Abades SR, Rivadeneira $\mathrm{MM}$, et al. Emergence of social complexity among coastal huntergatherers in the Atacama Desert of northern Chile. Proc Natl Acad Sci 2012;109(37):14754-60.

42. Toogood SJ, Diaper J. Developments in the assessment of odours from sludges. In: Nielsen VC, Voorburg JH, L'Hermite P, editors. Odour prevention and control of organic sludges and livestock farming. Oxford, U.K.: Taylor and Francis, 1986;162-8.

43. Juliá S. Víctimas de la Guerra Civil. Madrid, Spain: Editorial Temas de Hoy, 1999.

44. El Preston P. holocausto español. Madrid, Spain: Editorial Debate, 2012.

45. Congram D. Deposition and dispersal of human remains as a result of criminal acts. Homo sapiens sapiens as a taphonomic agent. In: Pokines JT, Symes SA, editors. Manual of forensic taphonomy. Boca Raton, FL: CRC Press, 2014;249-85.

46. Preston P. Revenge and reconciliation. Hist Tod 1989;39(3):28-33.

47. Graham H. The Spanish Civil War, 1936-2003: the return of Republican memory. Sci Soc 2004;68(3):313-28.

48. El Walker J. valle de Dios. Granta en español 1: el silencio en boca de todos. Barcelona, Spain: Emece, 2003;135-59.

49. Desfor Edles L. Symbol and ritual in the New Spain: the transition to democracy after Franco. Cambridge, U.K.: Cambridge University Press, 1998.

50. Ferrándiz F. Exhuming the defeated: Civil War mass graves in 21st-Century Spain. Am Ethnol 2013;40(1):38-54.

51. El Ferrándiz F. pasado bajo tierra. Exhumaciones contemporáneas de la Guerra Civil. Barcelona, Spain: Anthropos, Siglo Veintiuno, 2014.

52. Ríos L, Etxeberria F. The Spanish Civil War forensic labyrinth. In: Ferran O, Hilbink L, editors. ????. London, U.K.: Routledge, 2015.

53. Ríos L, Casado Ovejero JI, Puente Prieto J. Identification process in mass graves from the Spanish Civil War I. Forensic Sci Int 2010;199:e27-36.

54. Ríos L, Garcia-Rubio A, Martinez B, Alonso A, Puente J. Identification process in mass graves from the Spanish Civil War II. Forensic Sci Int 2012;219:e4-9.

55. Etxeberria F, Herrasti L, Pérez de la Iglesia L, Albisu C, Jiménez J, Cardoso $\mathrm{S}$, et al. Exhumación, identificación y causa de muerte en la fosa común de Aibar-Oibar (Navarra). Munibe 2012;63:367-77.

56. Serrulla F, Etxeberría F, Herrasti L, Cascallana JL, Del Olmo J. Saponified brains of the Spanish Civil War. In: Schotsmans EMJ, MárquezGrant N, Forbes SL, editors. Taphonomy of human remains, Forensic analysis of the dead and the depositional environment. Chichester, U.K.: Wiley, In press.

57. Aguilar P. Judiciary involvement in authoritarian repression and transitional justice: the Spanish case in comparative perspective. Int J Trans Justice 2007;7:245-66.

58. García Colmenares P. Víctimas de la guerra civil en la provincia de Palencia (1936-1945). Palencia, Spain: ARMH, 2012.

59. García Colmenares P, Moreno Lázaro J, Sánchez García JL. Historia de Palencia en los siglos XIX y XX. Palencia, Spain: El Norte de Castilla, 1996.

60. Estremera S. Technical report of the archaeological excavation carried out at La Carcavilla. Ayuntamiento de Palencia, Spain: Alacet Arquélogos, 2011.

61. Langley-Shirley N, Jantz RL. A Bayesian approach to age estimation in modern Americans from the clavicle. J Forensic Sci 2010;55(3):571-83.

62. Brooks S, Suchey J. Skeletal age determination based on the os pubis: a comparison of the Acsádi-Nemeskéri and Suchey-Brooks methods. J Hum Evol 1990;3:227-38.

63. Knittle E, Phillips W, Williams Q. An infrared and Raman spectroscopic study of gypsum at high pressures. Phys Chem Minerals 2001;28:630-40.
64. Martinez-Ramirez S, Sanchez-Cortes S, Garcia-Ramos J.V, Domingo C, Fortes C, Blanco-Varela MT. Micro-Raman spectroscopy applied to depth profiles of carbonates formed in lime mortar. Cem Concr Res 2003;33:2063-8.

65. Edwards HGM, Farwell DW. The conservational heritage of wall paintings and buildings: an FT-Raman spectroscopic study of prehistoric, Roman, mediaeval and Renaissance lime substrates and mortars. J Raman Spectrosc 2008;39:985-92.

66. Edwards HGM, Farwell DW, de Faria DLA, Monteiro AMF, Afonso MC, De Blasis P, et al. Raman spectroscopic study of 3000-year-old human skeletal remains from a sambaqui, Santa Catarina, Brazil. J Raman Spectrosc 2001;32:17-22.

67. Edwards HGM, Rull Perez F. Application of Fourier transform Raman spectroscopy to the characterization of parchment and vellum. II - Effect of biodeterioration and chemical deterioration on spectral interpretation. J Raman Spectrosc 2004;35:754-60.

68. Edwards HGM, Doménech-Carbo MT, Hargreaves MD, DoménechCarbo A. A Raman spectroscopic and combined analytical approach to the restoration of severely damaged frescoes: the Palomino project. J Raman Spectrosc 2008;39:444-52.

69. Jorge Villar SE, Edwards HGM, Medina J, Perez RF. Raman spectroscopic analysis of mediaeval wall paintings in the Palencia region, Spain. J Raman Spectrosc 2006;37:1078-85.

70. Chalmers JM, Edwards HGM, Hargreaves MD. Infrared and Raman spectroscopy in forensic science. Chichester: Wiley, 2012.

71. Edwards HGM, Chalmers JM. Practical Raman spectroscopy and complementary techniques. In: Edwards HGM, Chalmers JM, editors. Raman spectroscopy in archaeology and art history. Cambridge, U.K.: The Royal Society of Chemistry, 2005.

72. Aminzadeh A. Fluorescence bands in the FT-Raman spectra of some calcium minerals. Spectrochim Acta Mol Biomol Spectrosc 1997;53:693-7.

73. Aminzadeh A, Meskinfam M, Tayyary SF. Laser induced florescence bands in the FT-Raman spectra of bioceramics. Spectrochim Acta A 2007;66:199-201.

74. Tsuda H, Arias JL, Leon B, Arends J. Necessary precautions in the Raman analysis of calcium phosphate minerals using 1.06um YAG laser excitation. Appl Spectrosc 1998;52:1122-6.

75. Williams R. Limekilns and limeburning. Princes Risborough, U.K.: Shire Publications, 1989.

76. Munro NH, Green DW, Dangerfield A, McGrath KM. Biomimetic mineralisation of polymeric scaffolds using a combined soaking and Kitano approach. Dalton Trans 2011;40:9259-68.

77. Aranda JRE. El mundo rural en la España moderna. Ciudad Real, Spain: Universidad de Castilla La Mancha, 2004.

78. Philpott R. Burial practices in Roman Britain. A survey of grave treatment and furnishing AD 43-410. BAR British Series 219. Oxford, U.K.: Tempus Reparatum, 1991.

79. Reifarth N. Textiles in their scientific context. Interdisciplinary cooperation during the evaluation of burial textiles. In: Alfaro C, Brun J-P, Borgard P, Pierobon Benoit R, editors. Purpureae Vestes III textiles y tintes en la ciudad antigua. Valencia, Spain: Universitat de Valencia, 2011;101-7.

80. Nordby JJ. Is forensic taphonomy scientific? In: Haglund WD, Sorg $\mathrm{MH}$, editors. Advances in forensic taphonomy method, theory and archaeological perspectives. Boca Raton, FL: CRC Press, 2002;31-42.

81. Tulchinsky TH, Varavikova EA. The new public health. London, U.K.: Elsevier, 2009.

82. Aufderheide AC, Rodríguez-Martín C. The Cambridge encyclopedia of human paleopathology. Cambridge, U.K.: Cambridge University Press, 1998.

83. Larsen CS. Bioarchaeology. Cambridge, U.K.: Cambridge University Press, 1997.

84. Roberts CA. Human remains in archaeology: a handbook. CBA practical handbook. York, U.K.: Council for British Archaeology, 2009.

85. Waldron T. Paleopathology. Cambridge, U.K.: Cambridge University Press, 2009.

Additional information and reprint requests:

Eline Schotsmans, Ph.D.

De la Préhistoire à l'Actuel: Culture, Environnement et Anthropologie

PACEA UMR 5199

Université de Bordeaux, Bat. B8

Allee Geoffroy St Hilaire, CS 50023

33615 Pessac Cedex

France

E-mail: eline.schotsmans@live.be 


\section{Author Query Form}

\section{Journal: $\quad$ JFO}

Article: $\quad 13276$

Dear Author,

During the copy-editing of your paper, the following queries arose. Please respond to these by marking up your proofs with the necessary changes/additions. Please write your answers on the query sheet if there is insufficient space on the page proofs. Please write clearly and follow the conventions shown on the attached corrections sheet. If returning the proof by fax do not write too close to the paper's edge. Please remember that illegible mark-ups may delay publication.

Many thanks for your assistance.

\begin{tabular}{|c|c|c|}
\hline Query reference & Query & Remarks \\
\hline 1 & AUTHOR: Please check the edit made in the article title. & \\
\hline 2 & $\begin{array}{l}\text { AUTHOR: A running head short title was not supplied; please check if this } \\
\text { one is suitable and, if not, please supply a short title of up to } 40 \text { characters } \\
\text { that can be used instead. }\end{array}$ & \\
\hline 3 & $\begin{array}{l}\text { AUTHOR: Please confirm that given names (red) and surnames/family names } \\
\text { (green) have been identified correctly. }\end{array}$ & \\
\hline 4 & AUTHOR: Please check that authors and their affiliations are correct. & \\
\hline 5 & $\begin{array}{l}\text { AUTHOR: Please suggest whether the term "Civil War" could be changed as } \\
\text { "civil war" throughout the article expect in the occurence of "Spanish Civil } \\
\text { War". }\end{array}$ & \\
\hline 6 & $\begin{array}{l}\text { AUTHOR: Figure captions are extracted from the PDF source file. Please } \\
\text { check if this is okay. }\end{array}$ & \\
\hline 7 & AUTHOR: Table were given in picture format. Please check. & \\
\hline 8 & AUTHOR: Please provide the book title for reference [52]. & \\
\hline 9 & $\begin{array}{l}\text { AUTHOR: Figure } 1 \text { is of poor quality. Please check required artwork } \\
\text { specifications at http://authorservices.wiley.com/bauthor/illustration.asp }\end{array}$ & \\
\hline 10 & $\begin{array}{l}\text { AUTHOR: Figure } 8 \text { is of poor quality. Please check required artwork } \\
\text { specifications at http://authorservices.wiley.com/bauthor/illustration.asp }\end{array}$ & \\
\hline 11 & $\begin{array}{l}\text { AUTHOR: Figure } 9 \text { is of poor quality. Please check required artwork } \\
\text { specifications at http://authorservices.wiley.com/bauthor/illustration.asp }\end{array}$ & \\
\hline
\end{tabular}




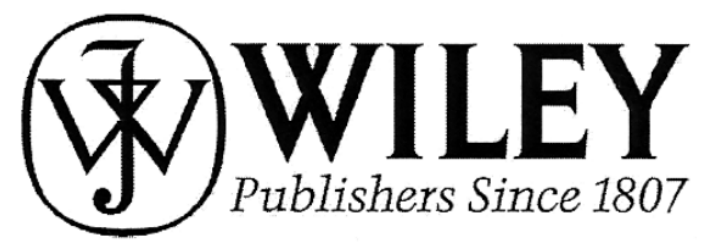

\section{COLOR REPRODUCTION IN YOUR ARTICLE}

Color figures were included with the final manuscript files that we received for your article. Because of the high cost of color printing, we can only print figures in color if authors cover the expense. The charge for printing figures in color is $\$ 650$ per figure.

Please indicate if you would like your figures to be printed in color or black and white. Color images will be reproduced online in Wiley Online Library at no charge, whether or not you opt for color printing.

Failure to return this form will result in the publication of your figures in black and white.

JOURNAL

VOLUME

ISSUE

TITLE OF MANUSCRIPT

MS. NO

NO. OF

COLOR PAGES

AUTHOR(S)

Please print my figures in black and white

Please print my figures in color

BILL TO:

Name

Institution

Address
$\$$

Purchase

Order No.

Phone

Fax

E - mail 